\title{
Social networking service in oral history research and education project
}

\author{
Tatiana V. Pushkareva ${ }^{1 *}$, Darya V. Agaltsova ${ }^{2}$, Elena M. Shemyakina ${ }^{3}$, and Ekaterina $Y$. \\ Ivanova $^{1}$ \\ ${ }^{1}$ Synergy University, Department of Visual Communication, Moscow, Russia \\ ${ }^{2}$ Financial University under the Government of the Russian Federation, Department of the English \\ Language and Professional Communication, Moscow, Russia \\ ${ }^{3}$ Moscow Pedagogical State University, Department of Cultural Studies, Moscow, Russia
}

\begin{abstract}
This article describes the experience of supplementing conventional Learning Management Systems (LMS) with Social Networking Service (SNS) aiming at analysis of historical memory of the Soviet past using the method of Oral History by Paul Thompson (1935). Opportunities of the Russian social network, VKontakte, were used for execution of research and education project: Family Memory of the Soviet Past (2014-2020) for students specializing in Culturology at Russian State Social University on the basis of Memory Studies and Oral History theories. This article presents the main educational and scientific results of the project. Using the SNS, the practical component of humanitarian education was implemented; the VKontakte project activity allowed involving student groups in researching; transcripts and photos were collected in digital archive, analysis and discussion were performed. The VKontakte network group demonstrated opportunities of international student research in post-Soviet countries, allowed students to master practical skills of acquisition and analysis of empirical data, as well as became an identification factor of a student group as a part of scientific community.
\end{abstract}

Keywords: research and education project, VKontakte social network, memory studies, oral history.

\section{Introduction}

Interest in the use of social media in the educational process is actively developing from the time of the first social networks emergence: already in 2010 the first application was developed and implemented for integration of educational programs and services of a popular social network [1]. A social network is a service for data exchange, the most massive type of online communications. Due to their multimillion audience, the social networks present such opportunities for education as sociological surveys for scientific research, arrangement and execution of educational telecommunication projects, education in the frames of specialized communities of social networks. Researchers mention such drawbacks of LMS as limitation and rigidity, exactly these drawbacks became the backside

* Corresponding author: ap-bib@yandex.ru 
of its universality and multifunctionality. It is mentioned that even such e-learning systems as Moodle (open source) do not allow using software by other developers without major tuning [2]. Criticism of limitations of traditional autonomous programs of learning management (e-learning, LMS) is sometimes very categoric: "Autonomous LMS departed this life ..." [3]. The system of social media on the basis of Web 2.0 technology transferred social communications to cardinally new level; over fifteen years of development of SNS/social media, new means of social interactions were allocated for common free access. However, all this is still little accounted for in traditional e-learning systems and in educational process in whole. The existing experience is not estimated too high by experts [4]; in fact, the SNS opportunities are at the very beginning of their mastering. However, at present under the conditions of distance learning, the use of various learning forms and means is especially required. Among the main advantages of social networks in educational projects, the following can be highlighted:

- openness: using this online service, all participants in the project can exchange information, creating and uploading learning content in the forms of comments, messages, blog;

- continuance: opportunities of education and research at any time are assumed, availability for participants in any time zone;

- interactivity: opportunity to work with various types of data (audio, video, graphics, texts).

In this regard, description, analysis, comprehension of experimental results of social networking in educational and scientific purposes seem to be relevant.

The project Family Memory of the Soviet Past (2014-2020) was carried out by Russian State Social University in cooperation with other universities [5]. The project was aimed at in-depth interviewing of respondents of older generations in order to reconstruct personal and family experience of the Soviet everyday life, at analysis of mentality of Soviet persons, as well as fixation of witness evidences of the past events. Comprehensive analysis of the obtained experience had to clarify the challenges and risks of SNS usage in educational process and in research of humanitarian students.

\section{Methods}

The multimedia project in this article is based and comprehended on the methods of Oral History international research. It is comprised of acquisition, archiving, analysis of historical data by interviewing witnesses, recording the interview on audio media and decoding (transcribing). Oral history, contrary to traditional written history, tries to hear and to fix the voices of those social groups, which due to various reasons were excluded from the system of written recording in archives, libraires, museums, media, and other institutions. Development of new technologies, common use of audio devices, and then the developed opportunity to store data in digital form on Internet: all these promoted intensive growth of oral history in early 1980 -s in Europe and the USA.

An important milestone in institutionalization and development of oral history was the activity by Paul Thompson (born 1935), who founded the Oral History Society and the Oral History journal. His book, The Voice of the Past (1977) [6], is one of the fundamental works disclosing the theory and practice of oral history. While discussing the causes of establishment of the movement, Thompson highlights one-sided character of written history: "The more personal, local, non-official was a document, the less chances it had to be retained. The governmental structure worked as a giant recording mechanism, forming the past in its own image and likeness" [7]. Considering autobiographies of common people as a source eliminates this gap and makes the history more multidimensional and more democratic. Thompson mentions that in group university projects of oral history, there 
occurs productive synthesis of research and teaching, which leads to improvement of quality of both [8]. Then it will be understood that this feature of group projects of oral history using social media/services not only successfully develops but also transits to a new qualitative level.

\section{Discussion}

Due to the works of Paul Thompson, the sound archive was established: National Life Stories [9], where histories of life of Britain society are collected. A part of this unusual national archive is available in Oral History collections at British Library [10] as well as in the frames of the project Millennium Memory Bank [11]. It should be mentioned that some of them are available only for the customers from accredited universities, that is, present material for student research. Institutionalized collections of oral histories are available in the USA, Czechia, Spain, Italy, Syria, China, as well as in post-Soviet territory: Uzbekistan and Belarus [12].

The studies of the past from the point of view of family, biographical focus in Russia started actually simultaneously with the development of Oral History in Europe and the USA, most of these projects are still successfully operating [13, 14, 15].

According to some data, SNS/social media for the purposes of higher education are used by less than $50 \%$ of teachers, most of them are humanitarians [16]. In general, academic mastering of SNS in higher education can be considered as an obligatory mastering of language of the new generation, known as digital native: the first generation fostered under conditions of Internet environment [17].

\section{Results}

The project Family Memory of the Soviet Past collected and analyzed empirical materials in the post-Soviet territory (Russia, Kazakhstan, Belarus) in the focus of family history. The project was performed from 2014 to 2020 and assumed studying the theories of Oral History, Memory Studies, qualitative sociology, and biographical method; face-to-face interviewing, transcript preparation, transcript reading and discussion in classroom, selection and analysis of photos, arrangement of electronic archive on the VKontakte page, network interaction among the participants, creation, writing, issuing research works. During the project it was possible to record and to transcribe about 90 interviews, some of them were published [18], to collect and to analyze more than 100 photos. In the course of the project, its network structure was formed: the respective closed VKontakte group.

Despite obvious educational and scientific successes of the Family Memory of the Soviet Past group, such practice had its bottlenecks. Thus, in the course of SNS, the boundary between private and educational space was in fact blurred. However, after termination of the project and total education, three fourth of students remained in the network group, which, in the authors' opinion, indirectly evidenced secured freedom of choice.

\section{Conclusion}

Thus, while performing the project titled Family Memory of the Soviet Past, new research and education opportunities of VKontakte SNS were revealed. The use of VKontakte network group, Family Memory of the Soviet Past, as a part of Culturology educational program provided opportunities for international student research in post-Soviet territory in the field of Oral History, expanded opportunities for mastering practical skills for 
acquisition and analysis of empirical material and promoted implementation of practical component of humanitarian education.

\section{Acknowledgments}

This work was supported by the Russian Foundation for Basic Research, Project No. 19-011-00943 titled Forward to the Past: Archaicism and Archaizing Trends in Contemporary Russian Society (interdisciplinary analysis) in collaboration with the regional public organization Community of Professional Sociologists.

\section{References}

1. London School of Business \& Finance, Revolyutsiya v mire obrazovaniya!

[Revolution in the world of education!] (2010). Accessed on: December 17, 2020.

[Online]. Available: http:www.lsbf.ru/news/lsbf-facebook

2. D. Pontefract, The Standalone LMS is dead (2009). Accessed on: December 17, 2020.

[Online]. Available: https://www.danpontefract.com/the-standalone-lms-is-dead

3. A.V. Feschenko, Gumanitarnaya informatika, 6, 124-134 (2012). Accessed on:

December 17, 2020. [Online]. Available:

http://vital.lib.tsu.ru/vital/access/manager/Repository/vtls:000430102

4. A. Kumi-Yeboah, H. Blankson, Social Media and Use of Technology in Higher

Education, in V.C.X. Wang (Ed.), Handbook of Research on Education and

Technology in a Changing Society, 217-234 (Florida Atlantic University, Florida, 2014). 10.4018/978-1-4666-6046-5.ch017

5. S.K. Tamazyan, Sotsial'naya interaktsiya v neformalizovannykh setyakh sovremennykh rossiyskikh podrostkov [Social interaction in non-formalized networks of modern Russian adolescents]. Dissertation of the candidate of sociological sciences (North Caucasus State Technical University, Stavropol, 2012)

6. T. Pushkareva, A. Bykova, Semeynaya pamyat' o sovetskom proshlom [Family memory of the Soviet past] (n.d.). Accessed on: December 17, 2020. [Online]. Available: https://vk.com/club67161829

7. P. Thompson, The Voice of the Past: Oral History (Oxford University Press, Oxford, 2000)

8. British Library, National Life Stories (2020). Accessed on: December 17, 2020. [Online]. Available: https://www.bl.uk/projects/national-life-stories

9. Britain Library, Oral history (n.d.). Accessed on: December 17, 2020. [Online]. Available: https://www.bl.uk/collection-guides/oral-history

10. Britain Library, Millennium memory bank (n.d.). Accessed on: December 17, 2020. [Online]. Available: https://sounds.bl.uk/Accents-and-dialects/Millenium-memorybank

11. Oral History (n.d.). Accessed on: December 17, 2020. [Online]. Available: https://en.wikipedia.org/wiki/Oral_history

12. Memorial, Konkurs dlya starsheklassnikov. Chelovek v istorii - 20th vek [Competition for high school students. Man in history - 20th century] (n.d.). Accessed on: December 17, 2020. [Online]. Available: http://www.memo.ru/s/6.html

13. O.B. Bozhkov, K.S. Divisenko, Russian Academic Journal Telescope: Journal of Sociological and Marketing Research, 3, 60-62 (2007) 
14. Nauchno-obrazovatel'nyy tsentr ustnoy istorii [Scientific and Educational Center for Oral History] (n.d.). Accessed on: December 17, 2020. [Online]. Available: http://historyvoice.ru

15. J. Palfrey, U. Gasser, Understanding the first generation of digital natives (Persus Book Group, Philadelphia, 2008)

16. T.V. Pushkareva (Ed.), Istoriya moyey sem'i v 20 veke. Materialy nauchnoissledovatel'skoy raboty studentov kafedry kul'tury i dizayna RGSU v ramkakh izucheniya distsipliny "Prikladnaya kul'turologiya" [The story of my family in the 20th century. Materials of research work of students of the Department of Culture and Design of the Russian State Social University in the framework of the discipline “Applied Culturology"]. Issue 1 (Moscow, Bookvika.ru, 2014)

17. A.A. Verbitsky, Electronic scientific journal "Homo Cyberus", 1(6) (2019). Accessed on: December 17, 2020. [Online]. Available: http://journal.homocyberus.ru/Verbitskiy_AA_1_2019

18. T.V. Pushkareva, Historical, Philosophical, Political and Law Sciences, Culturology and Study of Art. Issues of Theory and Practice, 6(56)(2), 151-153 (2015). Accessed on: December 17, 2020. [Online]. Available:

https://www.gramota.net/eng/materials/3/2015/6-2/41.html 